Proc. Estonian Acad. Sci. Geol., 2001, 50, 3, 174-189

\title{
ANDREOLEPIS (ACTINOPTERYGII) IN THE UPPER SILURIAN OF NORTHERN EURASIA
}

\author{
Tiiu MÄRSS \\ Institute of Geology, Tallinn Technical University, Estonia pst. 7, 10143 Tallinn, Estonia; \\ marss@gi.ee
}

Received 12 April 2001, in revised form 14 May 2001

\begin{abstract}
Localities with the actinopterygian Andreolepis in the northern part of Eurasia were revised. Andreolepis petri sp. nov. was established on the basis of distinct morphology and sculpture of the scales, and exoskeletal platelets in the Tabuska Beds, upper Ludlow or lower Prridoli of the Ufa River section, the Central Urals. Andreolepis was excluded from the family Lophosteidae Gross, 1969 and placed into a new family Andreolepididae fam. nov.
\end{abstract}

Key words: Andreolepis, Andreolepididae fam. nov., order incertae sedis, Actinopterygii, Osteichthyes, upper Ludlow-lower Přidoli, Upper Silurian.

\section{INTRODUCTION}

Since the original description of Andreolepis hedei Gross, 1968 from the Hemse Beds, middle Ludlow of Gotland Island, Sweden, several new localities of this taxon have been documented. Most of them are in northern Europe, and only few are known from northern Asia (Fig. 1). The aim of the present study is to review all known Andreolepis sites and describe A. hedei Gross and a new species, preliminarily identified also as $A$. hedei (e.g. Märss 1992), from the Central Urals. The inclusion of the genus Andreolepis into a new family will be discussed. 


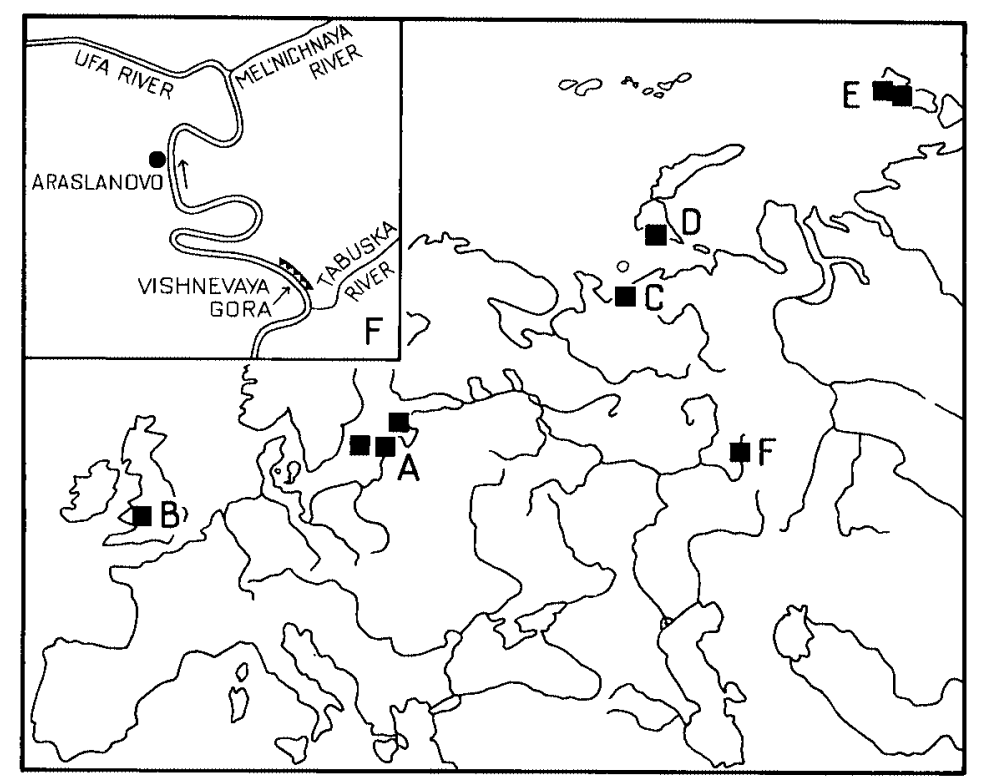

Fig. 1. Regions with Andreolepis findings. A, Baltic; B, British Isles; C, northern Timan; D, Novaya Zemlya Archipelago; E, Severnaya Zemlya Archipelago; F, Central Urals. Inset: location of the "Vishnevaya Gora" section on the right bank of the Ufa River (F).

\section{DISTRIBUTION OF ANDREOLEPIS}

\section{The Baltic area}

\section{Gotland Island}

Andreolepis hedei was first described (Gross 1968) on material from Gogs locality near Lau (SE Gotland), from the middle Ludlow Upper Hemse Beds corresponding to the Monograptus leintwardinensis Zone. It occurs together with the thelodont Phlebolepis elegans Pander, a heterostracan Archegonaspis sp., birkeniid anaspids, acanthodians Nostolepis striata Pander, Gomphonchus sandelensis (Pander), and Gomphonchus hoppei (Gross), and a taxon that has similarities with Thelodus parvidens Agassiz. Janvier (1978) described some fragmentary dermal platelets and more scales of $A$. hedei from the same locality.

Later, Fredholm (1988a, p. 174, 1988b, pp. 241-242, 1989) discovered nearly 30 new localities with A. hedei on Gotland Island belonging to the Hemse limestone units $\mathrm{d}$ and $\mathrm{e}$, and the Hemse marls. A. hedei appears below the Polygnathoides siluricus conodont Zone and disappears above this zone in the uppermost Hemse Beds (Fredholm 1988b, p. 245). Fredholm's collection of $A$. hedei is rather rich, comprising about 580 scales. She listed slightly different taxa in the assemblage than Gross (1968): in addition to some common taxa, the assemblage includes Thelodus carinatus (Pander), Archegonaspis lindstroemi 
Kiaer, and sporadically Paralogania martinssoni (Gross), whereas Thelodus parvidens Agassiz and Gomphonchus hoppei (Gross) are absent. In the Uddvide outcrop in the Burgsvik Sandstone the assemblage with A. hedei contains Paralogania ludlowiensis (Gross), Zenaspis? sp., Nostolepis striata Pander, Gomphonchus sandelensis (Pander), and a birkeniid anaspid (Märss 1992). The findings of $A$. hedei from marlstone and limestone facies show that it inhabited marine environments (Fredholm 1988b).

\section{Saaremaa Island and western Latvia}

On Saaremaa Island, Estonia, scales of Andreolepis hedei are seldom discovered in nodular biomicritic limestones and dolomitic marlstones of the Tahula-709 drill core, at a depth of $11.6 \mathrm{~m}$, and Sakla drill core, at 14.47-14.65 m. They occur also in argillaceous nodular limestones in the Ohesaare drill core (depth 98.9-99.5 m). All these findings come from the Uduvere Beds of the Paadla Stage. In western Latvia, the scales have been found in three samples of the Ventspils drill core, at 472.4, 474.8, and $484.5 \mathrm{~m}$, corresponding to the Mituva Formation of the Paadla Stage (middle Ludfordian, Upper Ludlow) (Märss 1986). Other vertebrates comprise Thelodus sp., Phlebolepis elegans, Archegonaspis sp., Osteostraci gen. et sp., Nostolepis striata, and Gomphonchus sandelensis. The Mituva Formation is characterized by unsorted skeletal packstone of open shelf facies belt (Gailite et al. 1987).

\section{British Isles}

Scales of an actinopterygian from the Long Quarry Beds, lower Přidoli (erroneously treated as Ludlow in Märss 1992), in Capel Horeb Main Quarry, southern Wales, were preliminarily identified as Andreolepis hedei? Gross (Märss 1986). Samples were taken from the lower grey carbonaceous siltstone beds, where A. hedei? occurs together with Thelodus parvidens, a cyathaspid (Archegonaspis sp.), and remains of two acanthodian taxa, $N$. striata and $G$. sandelensis. Scanty Andreolepis material comprises a few scales with more or less smooth surfaces typical of small scales of $A$. hedei, and a scale with elongate spiny tubercles unknown for the species at that time (Märss 1986, pl. 34, fig. 2). Turner $(2000$, pl. 6, figs. 14, 15) figured one scale of $A$. hedei from the same locality and beds about $9 \mathrm{~m}$ above the junction with the Roman Camp Formation.

\section{Northern Timan}

Andreolepis hedei was first identified from the key section of the Velikaya Reka (Velikoretskaya) Formation, Gerd"yu Stage, Ludlow, on the Velikaya River in the northern Timan (Kossovoj \& Karatajūte-Talimaa 1977). Its rare scales occur together with scales of thelodonts Thelodus marginatus Karatajūte-Talimaa, Paralogania martinssoni (Gross), Phlebolepis elegans Pander, osteostracans Tremataspis sp. ind., Thyestes? sp. ind., Dartmuthia? sp. ind., acanthodians, and shield fragments of heterostracan(s) (ibid.). The same assemblage with A. hedei was found also in the Udachnaya-1 drill core, Nar'yan-Mar field, in the middle 
part of the Gerd"yu Stage (Talimaa \& Mel'nikov 1987). Scales from the Velikaya Reka Formation come from greyish or reddish calcareous siltstones and sandstones, and limestones. The scales were very frequent in the siltstones of the uppermost part of the formation. According to Talimaa \& Mel'nikov (1987, pp. 57-60; see also Valiukevičius et al. 1983), the sedimentation took place in extremely shallow water conditions.

\section{The Novaya Zemlya Archipelago}

The scales of Andreolepis hedei have been discovered in the uppermost part of the West Khatanzej Formation on the Khatanzej Peninsula. The formation consists of dark grey laminated or nodular limestones with rich and variable shelly fossils (Nekhorosheva 1981). Two samples, 7708-8 and 7708-8a, given for study by L. V. Nekhorosheva, contain only two $A$. hedei scales one of which is stored in Vilnius (Karatajūte-Talimaa 1981, pl. 52, fig. 11a,b) and the other in Tallinn.

\section{The Severnaya Zemlya Archipelago}

The material used in this review was collected by several expeditions during 1973-79 (see Matukhin \& Menner 1999a). Andreolepis hedei was found in few samples from October Revolution, Pioneer, and Komsomolets islands.

On October Revolution Island, scales of Andreolepis? were collected (identifications by V. Talimaa in Matukhin et al. 1999, p. 30) from bed 5-1 of locality 2 in the middle course of the Matusevich River from the upper part of the Ludlow Ust-Spokojnaya Formation. They come from grey and greenish-grey limestones with thin interlayers of clay containing also ostracodes, bivalves, and scales of thelodonts, fragments of osteostracans and anaspids.

A few A. hedei scales have been found north of Kovalevskij Bay on SW Komsomolets Island. They occur in the Ust-Spokojnaya Formation in grey and greenish-grey, rarely reddish limestones and dolostones with oolitic and oncolitic thin sandy or silty interlayers. A. hedei has also been recorded from the same formation at the northern coast of Pioneer Island from grey, greenish-grey and reddish ostracode and algal floatstones, oolitic packstones, and marls with sandstone and siltstone interlayers (Matukhin et al. 1999). Besides A. hedei, remains of several thelodont and osteostracan agnathans were found on both islands (Klubov et al. 1980; Märss 1982; Matukhin et al. 1999, p. 31; samples 2055zh and 2463 from Pioneer Island are in the author's possession). All Andreolepis findings from Pioneer, Komsomolets, and October Revolution islands come from the same stratigraphical level, from the upper part of the Ust-Spokojnaya Formation, Ludlow. Matukhin \& Menner (1999b, p. 150) interpreted the corresponding beds as a lithofacies of extremely shallow-water restricted shelf.

\section{The Central Urals (Ufa Amphitheatre) Mikhailovsk Subzone}

Vertebrate remains form several thin bone bed interlayers in the argillaceous limestones in the upper part of the stratotype of the Kuba Beds (lower Ludfordian, 
Ludlow) in the Mikhailovsk Pond southern section. Over 250 Andreolepis hedei scales that are usually broken and about 10 small dermal bone fragments have been found in six samples taken from three ditches (911-A-18; 911-Б-16, 911-Б-18; 911-B-23, 911-B-24, 911-B-25). A. hedei occurs together with Thelodus carinatus (Pander), Phlebolepis elegans Pander, Paralogania martinssoni (Gross), Archegonaspis? sp., Tremataspis cf. milleri Patten, Thyestes sp., Procephalaspis sp., and an acanthodian of Gomphonchus sandelensis-type. The Kuba Beds represent shallow marine sediments (Chekhovich et al. 2001).

\section{Serga Subzone}

Scattered Silurian bedrock blocks occur in an about $250 \mathrm{~m}$ long stripe along the right bank of the Ufa River, downstream the mouth of the Tabuska River (Fig. 1F). These are dark grey, thin- to medium-bedded limestones with argillaceous shale intercalations, overlain by dark grey lithoclastic limestones. The rocks constitute the Tabuska Beds and correspond to the lower Pridoli (Shurygina et al. 1981; Shujskij 1981) or upper Ludlow (Modzalevskaya \& Märss 1991). Andreolepis scales have been found in five samples (777, 85-042, $85-47,83146-5,85146-5 b$ ) of somewhat uncertain stratigraphic position. Other vertebrates in the samples comprise Thelodus parvidens Agassiz, Thelodus sculptilis Gross, two to three different cyathaspidid heterostracans, two anaspids, two osteostracans, and acanthodians Nostolepis striata Pander, Gomphonchus sandelensis (Pander), and Poracanthodes porosus Brotzen. Preliminarily the scales of Andreolepis were identified as A. hedei Gross. More detailed study of this material revealed differences in their scale sculpture as compared with that of typical A. hedei from the Hemse Beds in the type locality Gogs on Gotland, but also from the Kuba Beds of the Mikhailovsk Pond section in the Central Urals.

\section{Remarks}

The presence of Thelodus sculptilis, the index-species of the next, higher standard vertebrate zone and the absence of Phlebolepis elegans in the Tabuska Beds allow us to correlate these beds with the Upper Ludlow Kuressaare Stage of the East Baltic. In the latter case T. sculptilis reaches into the Pridoli Kaugatuma Stage, but Andreolepis does not. In Britain, the Long Quarry Beds, Prridoli, yield Andreolepis hedei? as well as Andreolepis hedei but not Thelodus sculptilis scales.

Märss (1992) established that Andreolepis hedei occurs together either with an older vertebrate assemblage (T. carinatus, P. elegans, etc.; Uduvere Beds of the Paadla Stage, limestone units d and e of the Hemse Beds, Hemse marls, Kuba Beds, Ust-Spokojnaya Formation, West Khatanzej Formation, and Velikaya Reka Formation) or a younger assemblage (T. parvidens, T. sculptilis, and Paralogania ludlowiensis, in Long Quarry Beds, Tabuska Beds, and Burgsvik Sandstone, respectively). 
For the moment, it is clear that at least one new Andreolepis species is present in the younger vertebrate assemblage that is either late Ludlow or early Prridoli in age. More material is needed for exact identification of the species of Andreolepis in the Long Quarry Beds and Burgsvik Sandstone. All Andreolepis finds come from marine deposits, from nearshore shallow water up to deeper parts of the shelf.

\title{
SYSTEMATIC DESCRIPTION
}

The Andreolepis hedei and A. petri sp. nov. scale and platelet collection is housed in the Institute of Geology at Tallinn Technical University under registration number TTU GI 316.

\author{
Class OSTEICHTHYES Huxley, 1880 \\ Subclass ACTINOPTERYGII KLEIN, 1885 \\ Order incertae sedis \\ Family Andreolepididae fam. nov.
}

Content. Type genus only.

Diagnosis. Actinopterygians with head platelets covered with rounded tubercles or short ridges; scales are rhombic and carry longitudinal ridges surrounded by pores of vascular canals; a keel occurs on the visceral surface; lateral line canals are placed longitudinally in scales and open on the surface by pores. Scales are built from several generations of ridges; ridges consist of orthodentine and are covered by thin single-layered ganoine; bases of ridges of all generations and the base of the whole scale are built from cellular bone; the scales between the base and uppermost dentine layer are spongious.

Range. Middle part of Ludlow-lower Přidoli, Upper Silurian.

Genus Andreolepis Gross, 1968

Content. Andreolepis hedei Gross, 1968; Andreolepis petri sp. nov.

Diagnosis. Scales $1.0-4.5 \mathrm{~mm}$ long. Large scales carry ridges separated by grooves either only anteriorly or over the whole surface, the posterior margin is uneven or ends with spikes; overlapped area can be very wide, the antero-lateral process is rather long. Small scales have short ridges anteriorly, a flat surface medially and posteriorly; the posterior margin ends with one point; the overlapped area is narrow and the antero-dorsal process very short or absent. On the visceral side of the base there is a keel, or up to two elongate ridges and a groove between them.

Range. As for family. 


\section{Andreolepis hedei Gross, 1968}

Plate I

Diagnosis. See Gross, 1968.

Distribution. Gotland Island (Sweden); Saaremaa Island (Estonia); western Latvia; the northern Timan, Novaya Zemlya and Severnaya Zemlya, the Central Urals (Russia); middle Ludlow, Upper Silurian. Specific content of Andreolepis from the lower Přidoli is not yet clear.

Remarks. Both platelets and scales of A. hedei Gross have been found in the Kuba Beds, lower Ludfordian, Ludlow. Small platelets carry rounded or elongate tubercles (Pl. I, fig. 2) which sometimes are abradded (Pl. I, fig. 1), or platelets are covered with short bits of irregular, bifurcating and joining ridges that taper posteriorly (Pl. I, figs. 3, 4). The scales (Pl. I, figs. 5-14) are elongate to deep rhomboidal (scales on Pl. I, figs. 6,7 are deeper than long), the free field has anteriorly up to four sets of complex ridges that become united on the main free field (Pl. I, figs. 5-10), or the surface is covered with one wide ridge that carries few short slanting ridgelets on both sides (Pl. I, figs. 11, 12(?), 13, 14). The upper surface of the ridges can be smooth or slightly uneven; the free field ends with one posterior point. Numerous vascular canals open on the surface around the ganoine covered surface. Viscerally the base can be smoothly convex or has a keel.

Andreolepis petri sp. nov.

Plate II

Etymology. petri, after Dr. Petr Chekhovich (Institute of Lithosphere of Marginal Seas of the Russian Academy of Sciences), a good colleague and one of the leaders of the expedition to the Central Urals.

Holotype. Scale TTU GI 316-7; Plate II, fig. 8.

\section{Explanation of Plate I}

Figs. 1-14. Andreolepis hedei Gross. 1, 2, small platelets with rounded or short tubercles from the head region (in fig. 1 the tubercles are abraded); 3, 4, elongate platelet and a fragment of another, larger platelet both having the same type of sculpture of smooth-topped short ridges; $5-14$, scales from different parts of the trunk: $5,6,10,11,13$, scales of the left flank; 7-9, scales of the right flank; 12,14 , very narrow scales from a fin(?) region. The arrows point in rostral direction.

1, TTU GI $316-17, \times 10 ; 2$, TTU GI $316-18, \times 23 ; 3$, TTU GI $316-34, \times 29 ; 4$, TTU GI $316-25, \times 24$; 5, TTU GI $316-22, \times 23 ; 6$, TTU GI $316-36, \times 38 ; 7$, TTU GI $316-26, \times 26 ; 8$, TTU GI $316-24, \times 31$; 9, TTU GI $316-30, \times 36 ; 10$, TTU GI $316-37, \times 37 ; 11$, TTU GI $316-32, \times 40 ; 12$, TTU GI $316-33$, $\times 32 ; 13$, TTU GI $316-38, \times 57 ; 14$, TTU GI $316-39, \times 46$.

Figs. 1, 3, 6, 7, 10, 11, 13, 14, sample 911-A-18; figs. 2, 5, 9, sample 911-B-24; figs. 4, 8, 12, sample 911-Б-18; Mikhailovsk Pond southern section, the Central Urals, Russia; upper part of the Kuba Beds, lower Ludfordian, upper Ludlow, Upper Silurian. 
PLATE I

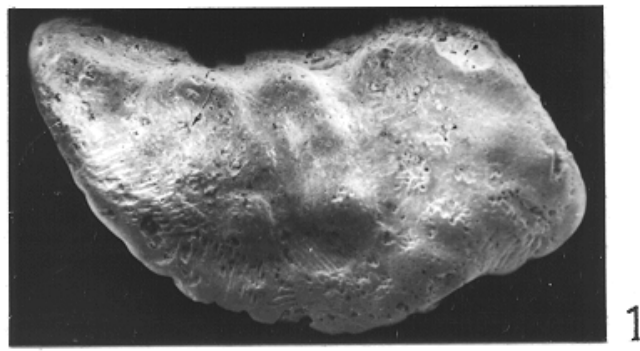

1

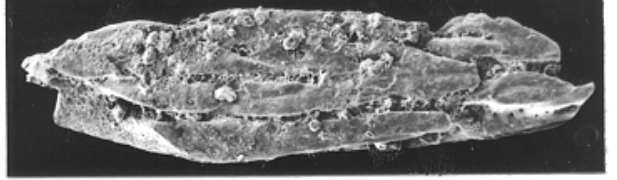

2
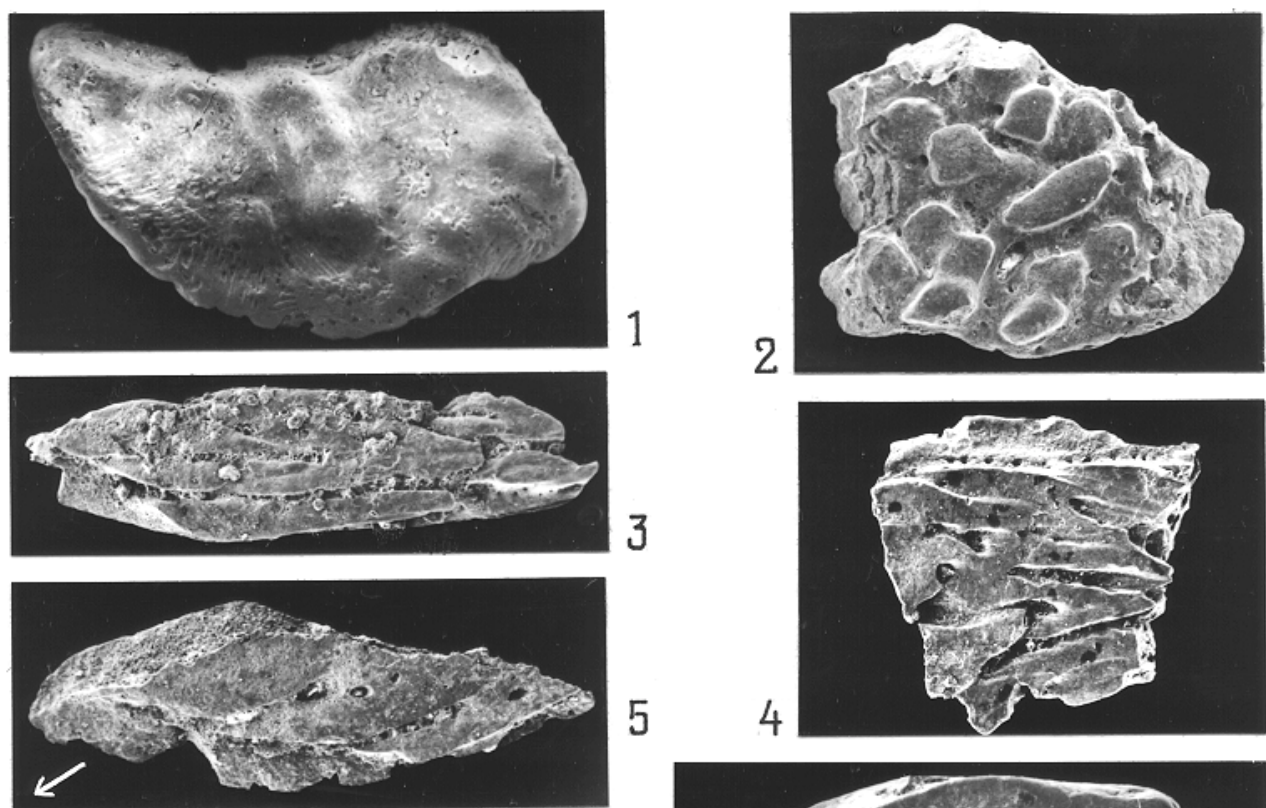

3
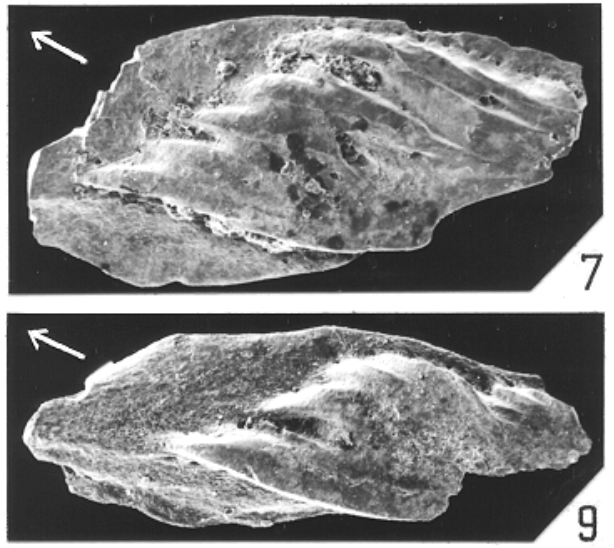

5
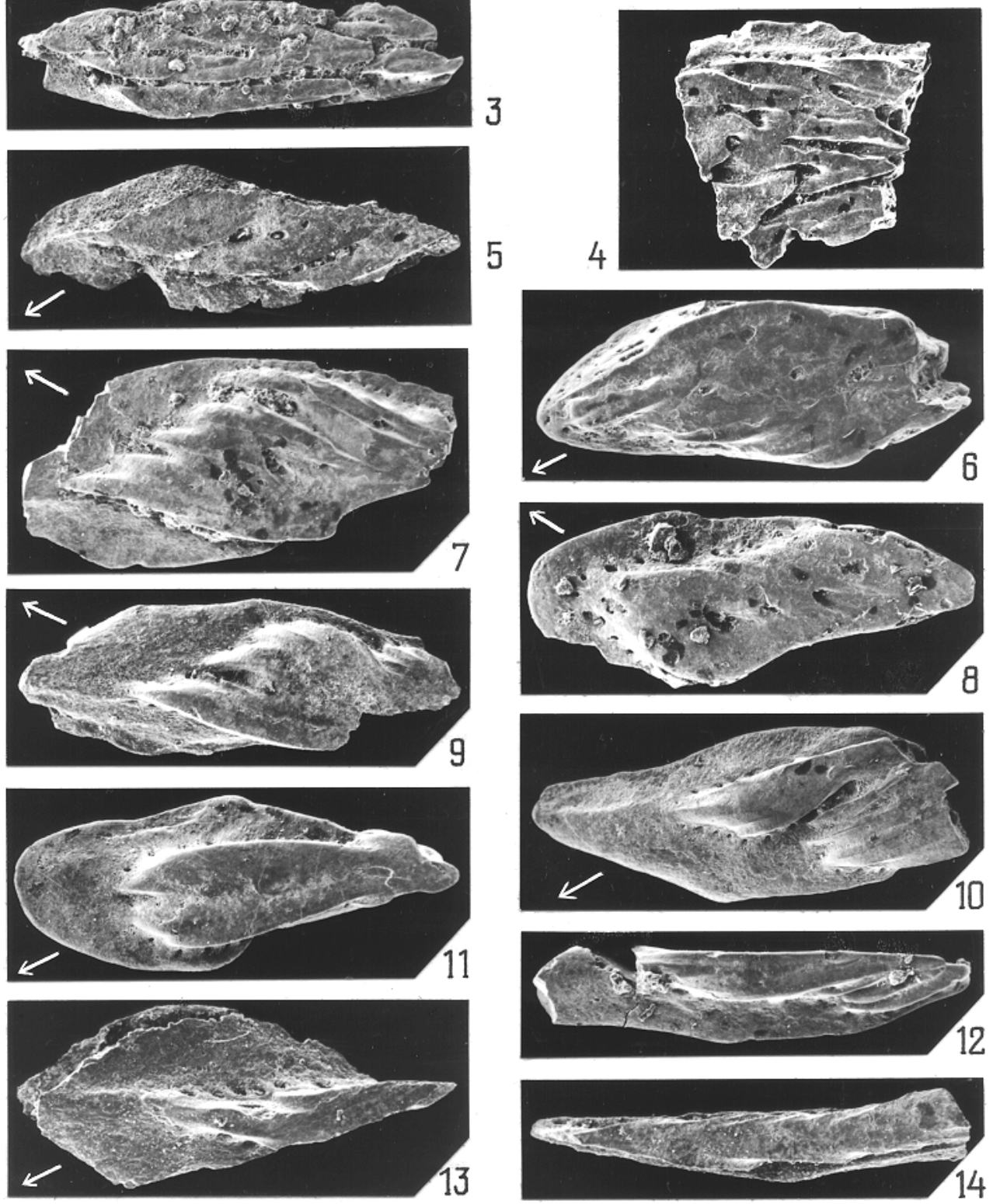
PLATE II
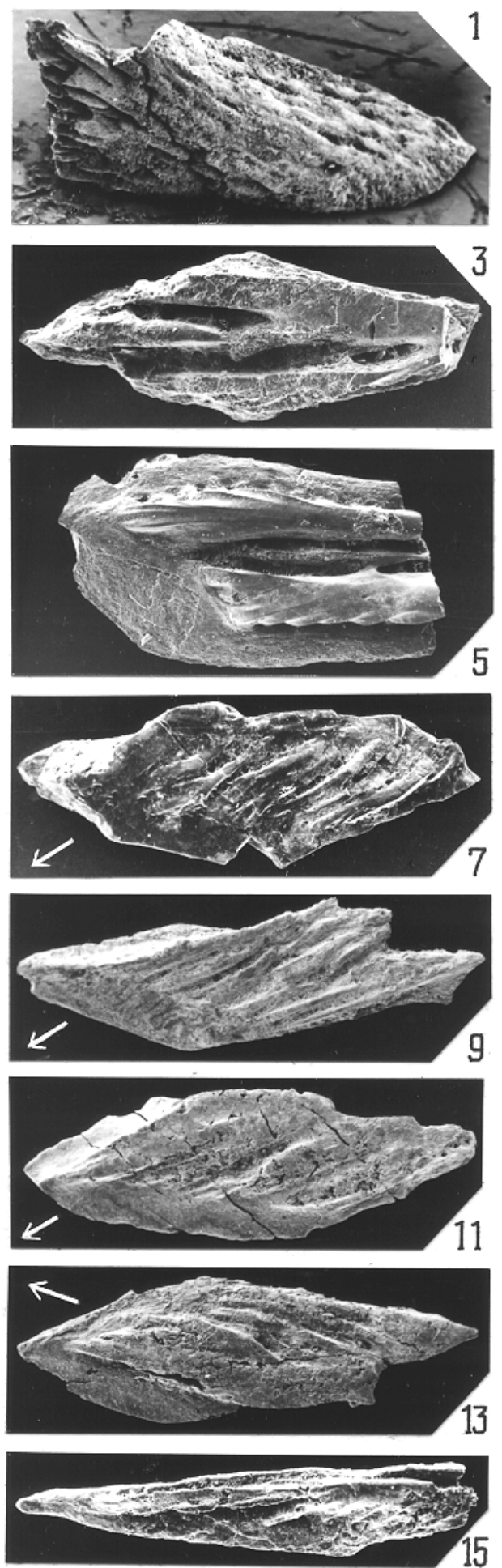
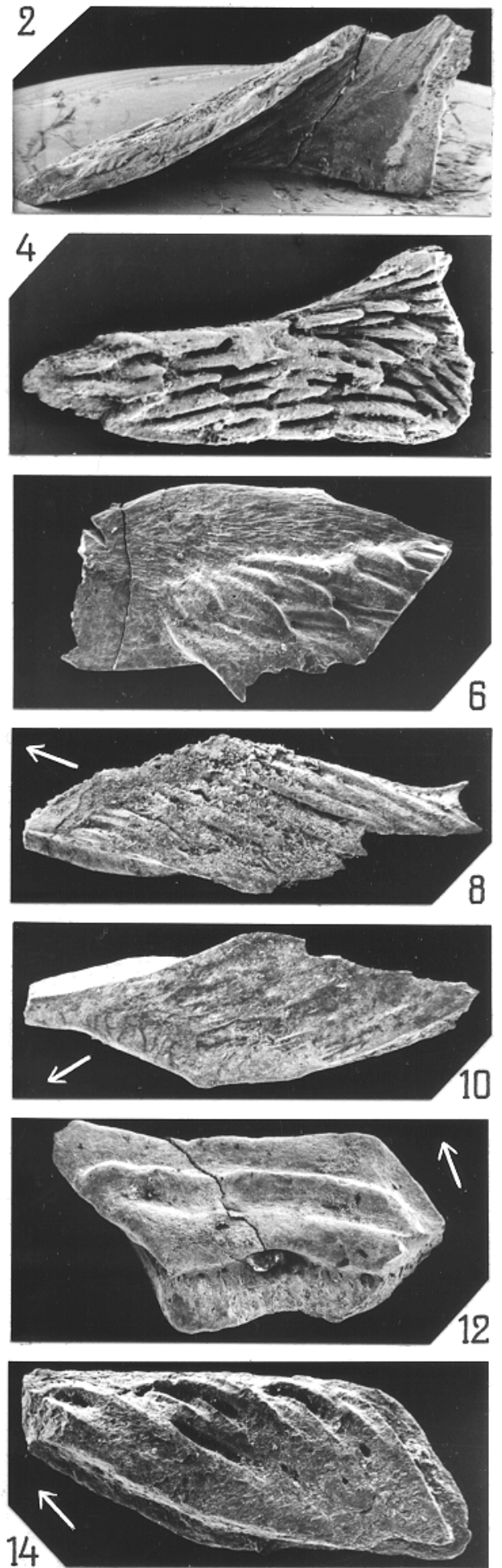
Type locality and horizon. Sample 85-146-5, "Vishnevaya Gora" section, right bank of the Ufa River, downstream from the mouth of the Tabuska River, the Central Urals, Russia; Tabuska Beds, upper Ludlow or lower Přidoli, Upper Silurian.

Material. 25 scales, about 10 platelets, and one spine; all specimens are broken to some extent, black in colour and have tight mini-cracks, which makes histological studies impossible.

Diagnosis. The spine and head platelets are covered with elongate tubercles or short ridges. Scales are elongate or deep rhomboidal and flattened; the free field carries up to nine nearly parallel ridges each terminating with a spike, or the posterior margin is uneven; ridges are separated from each other by very narrow grooves. Overlapped and overlapping areas are well developed. Antero-dorsal process of the base is relatively long; viscerally occurs a dorso-ventrally directed keel.

Description. A few broken platelets, a spine and scales of Andreolepis petri sp. nov. were found. The spine (Pl. II, figs. 1,2) has a wide basal portion and a gradually tapering distal end. The ridges are very irregular in shape and length and have smooth tops and margins on the external surface. Anterior ridges often end in a fork formed by posterior ridges. At least two overlapping generations of sculpture are visible on the left side of fig. 1, at the broken posterior margin. Very small pores of vascular canals open inside the spine. A small platelet (Pl. II, fig. 3) has the same type of sculpture as the spine.

Another type of sculpture is on a platelet (Pl. II, fig. 4) that bears very short, posteriorly pointed, slightly irregularly distributed ridges which curve downwards on the distal part of the platelet; four rows in the upper right corner run in the same direction as the ridges on the main part. Relatively coarse and fine

\section{Explanation of Plate II}

Figs. 1-15. Andreolepis petri sp. nov. 1, 2, a spine in external and visceral view; 3-6 platelets; 7, an aberrant scale of the left flank; $8-15$, scales from different parts of the trunk (12, in internal side): $9-11$, scales of the left flank; $8,12-14$, scales of the right flank; 15 , a narrow scale from the posterior part of the body. The arrows point in rostral direction.

1,2 , TTU GI $316-3, \times 11, \times 10 ; 3$, TTU GI $316-16, \times 56 ; 4$, TTU GI $316-2, \times 10 ; 5$, TTU GI $316-12$, $\times 45 ; 6$, TTU GI $316-13, \times 25 ; 7$, TTU GI $316-6, \times 21 ; 8$, Holotype TTU GI $316-7, \times 19 ; 9$, TTU GI $316-5, \times 17 ; 10$, TTU GI $316-4, \times 17 ; 11$, TTU GI $316-8, \times 23 ; 12$, TTU GI $316-1, \times 19 ; 13$, TTU GI $316-9, \times 24 ; 14$, TTU GI $316-10, \times 44 ; 15$, TTU GI $316-15, \times 53$.

Figs. 1, 2, 4, 5, 7, 9, 10, 15, sample 85-042; figs. 3, 6, 8, sample 85-146-5; figs. 11, 13, sample 86-146-5b; figs. 12, 14, sample 85-47; small ditches on the "Vishnevaya Gora" section, along the right bank of the Ufa River, downstream from the mouth of the Tabuska River, the Central Urals, Russia; Tabuska Beds, uppermost Ludlow or lower Přidoli, Upper Silurian. 
ridges occur together on the platelet, and they all have fine ridgelets on sides. A small platelet (Pl. II, fig. 5) carries short ridges with fine ridgelets on both sides similar to Pl. II, fig. 4. Most fragmentary platelets are flattened and have a smooth visceral surface.

A third type of sculpture occurs on a platelet with a very wide anterior and antero-dorsal overlapped area (Pl. II, fig. 6). The sculpture is from short triangular, posteriorly pointed smooth tubercles, the anterior tubercles partly covering the posterior ones. Each tubercle has a short shallow medial longitudinal groove anteriorly. This platelet carries very fine longitudinal striations on the anterior overlapped area (the upper side in fig. 6).

The scales of Andreolepis petri sp. nov. (Pl. II, figs. 7-15) are relatively large (the maximum length from the antero-dorsal to the postero-ventral corner is up to $4.5 \mathrm{~mm}$, usually $1.0-3.4 \mathrm{~mm}$ ) and have elongate to deep rhomboidal configuration. The most characteristic feature is the richly ridged surface of large, flattened, relatively thin juvenile scales (Pl. II, figs. 8-11, 13). They can have up to nine separate ridges and grooves distributed rostro-caudally over the free field, the ridges being wider than the grooves. Ridges, having fine ridgelets anteriorly and on both sides, arise smoothly from the base and terminate with free spikes posteriorly. The ridges of the latest generations become wider and the interridge grooves shallower in more adult scales, the posterior portion of the free field smoother, and the posterior margin indented with about five points (Pl. II, figs. 8-11, 13). On one scale (Pl. II, fig. 9) the regular course of ridges is disturbed; maybe the scale was wounded and later healed with irregularly arranged ridges. Small scales have steeply arising ridges at the anterior margin of the free field, the surface becomes smoother posteriorly (Pl. II, fig. 14). On the posterior part of the ganoine of an adult scale(?) only the rows of fine pores mark the course of interridge grooves. Very narrow scales from the posterior part of the body carry only one narrow longitudinal ridge (Pl. II, fig. 15). On an aberrant scale(?) (Pl. II, fig. 7) that has a relatively strong process antero-dorsally, the sculpture occurs only in the central part of the free field, not reaching the margins of the scale.

The scales can have rather wide, smooth overlapped (Pl. II, figs. 8-11) and overlapping areas. The visceral dorso-ventral keel forms two nearly parallel smaller ridges; the anterior ridge is relatively narrower, and the posterior wider and stronger (Pl. II, fig. 12).

One scale found is penetrated by a very short canal of the sensory line (Pl. II, fig. 12). The canal starts externally anteriorly in front of the free field and terminates behind the posterior margin of the keel. This is the first evidence showing that in the dermal skeleton of Andreolepis (A. petri sp. nov.) the sensory line was enclosed into canals which opened onto the surface of the scales.

Comparison. The genus Andreolepis is represented by two species, A. hedei Gross and A. petri sp. nov. In general, Andreolepis petri sp. nov. has larger scales, and the number of ridges on the free field is much higher. Its large juvenile scales 
may carry up to nine ridges on the entire length of the free field and have a narrow space between the ridges; their posterior margin has up to nine spikes (usually five) or the margin is uneven. The large scales of A. hedei carry complexes of ridges only anteriorly, which end with one posterior point. Small scales of these species have a different number of ridges. In A. petri sp. nov. small adult scales are formed by ridges and grooves anteriorly; the free field is smooth posteriorly while the interridge grooves are traceable only by pore rows. In A. petri sp. nov. there are 3-4 rows of small pores. In A. hedei Gross the ridges of the free field are united or they have just one ridge; the scale surfaces have less such pores or even lack them, therefore being more compact. Spines and platelets of the exoskeletons of both species are very rare in the residues. In A. hedei the sculpture of platelets is composed of rounded smooth tubercles (Gross 1968, fig. 13) originating, perhaps, from the snout, or of triangular, slightly elongate smooth tubercles that become longer and sinuous more posteriorly on the plate (Janvier 1978, pl. 1; text-figs. 1, 2). A. petri sp. nov. has short bits of ridges or joining/bifurcating ridges on the platelets; the sculpture is higher and longer than in $A$. hedei. A short canal of the sensory line system was detected in A. petri sp. nov. On the dermal plate of A. hedei, Janvier (1978, fig. 1) found a row of foramina near the ventrolateral angle on the inner surface of the right cleithrum. According to him, no real sensory line canal or groove was visible on the outer surface, but the row of foramina might have affected the conditions of a pit-line and could be the homologue of the ventral longitudinal sensory line of some agnathans (Janvier 1978, p. 90).

Scales of A. hedei were covered by a very thin ganoine layer (Schultze 1977, p. 158, pl. 13, fig. 3), which is also called single-layered ganoine (term used by Schultze 1968 for Orvikuina, Dialipina, and Ligulalepis; and by Richter \& Smith 1995 for Andreolepis). The histology of A. petri sp. nov. has not been studied due to bad preservation of the internal structure of the scales.

\section{DISCUSSION}

When Gross (1968) established the new taxon Andreolepis hedei he found that most of the morphological, histological, and morphogenetical characteristics matched with those of Devonian Palaeonisciformes. He also found that some histological features of Andreolepis were reminiscent of the structure of the spines and scales of the Silurian acanthodian Nostolepis. Based on the close similarity of the structure, Gross (1969) placed the genera Andreolepis Gross and Lophosteus Pander in the new family Lophosteidae and in the new order Lophosteiformes, indicating a possible close connection with the Actinopterygii.

Schultze (1977) compared the morphology and histology of Andreolepis and Lophosteus scales and bone elements. He found a thin layer of ganoine, called single-layered ganoine, in the scales of A. hedei (see above). Schultze also 
supported Gross's position that Andreolepis is the most primitive actinopterygian and considered (Schultze 1996, p. 222) Lophosteus the earliest osteichthyan which cannot be placed among either the actinopterygians or sarcopterygians.

Janvier (1978, p. 94) supported Gross's (1969) statement that A. hedei, belonging to the order Lophosteiformes, is a representative of the class Actinopterygii. After Janvier, this order might precede the Palaeonisciformes in the evolution of the class.

Otto (1991) described a fin spine of Lophosteus superbus Pander. He decided that such a fin spine could not belong to an actinopterygian or to a sarcopterygian, but had a similar shape with some acanthodian spines. Therefore lophosteids might stay between acanthodians and osteichthyans.

I agree with the original opinion of Gross (1969) that Andreolepis is an early actinopterygian, and with Schultze (1996) that Andreolepis Gross and Lophosteus Pander are not very closely related. According to the comparison by Schultze (1977, pp. 153-159), the histology of these genera is different as ganoine was found in Andreolepis and not in Lophosteus scales. It also seems to be true that in these two taxa the lateral line canals are situated differently in the dermal skeleton. Andreolepis does not show any dermal element with any open lateral line canal (Janvier 1978, p. 90), but a short closed canal was found in a scale of A. petri sp. nov., as described above. This canal is very similar to the lateral line canal in Ligulalepis toombsi (Schultze 1968, text-fig. 2a,b). Lophosteus has rather wide and deep open lateral line canals on the dermal platelets between the tubercles (Gross 1969, text-figs. 5H, 6D, 7A,B; Märss 1986, pl. 35, figs. 6, 7). The sculpture of stellate tubercles and open lateral line canals of Lophosteus platelets have superficial similarities with some placoderms, for example, with radotinids. On the other hand, the scale morphology and sculpture of Andreolepis are comparable with Orvikuina Gross (in Gross 1968). In both Orvikuina and Andreolepis the scales are rhombic, often rather long, with a "pillow-like" thickening viscerally, but no deep and narrow scale has been found. Lophosteus, however, has very deep scales which can be 4.5 times deeper than long. Such scales were situated anteriorly of the trunk while posteriorly they became rhomboidal or rhombic. Considering the above, Andreolepis is clearly different from Lophosteus and should be excluded from the family Lophosteidae Gross, 1969 and placed into a new family of the earliest actinopterygians, leaving the order level open.

\section{ACKNOWLEDGEMENTS}

The samples from the Central Urals were collected by the field expeditions during 1973-86, organized by A. Zhivkovich and P. Chekhovich. The samples from Novaya Zemlya were given for study by L. Nekhorosheva in 1970. The samples from Pioneer Island were provided by V. Lenkin and A. Khapilin. The discussions with E. Sytchevskaya on the dermal skeleton of early actinopterygians 
were very useful. V. Mikli made SEM photographs, G. Baranov prepared the prints, and K. Ronk made the drawing. The referees H.-P. Schultze and H. Nestor improved the manuscript by advising on the terminology of actinopterygian scales and facies interpretation, respectively. This study was supported by the Estonian Science Foundation (grant No. 4160). The help of all the above mentioned people and institutions is acknowledged.

\section{REFERENCES}

Chekhovich, P., Zhivkovich, A., Märss, T. \& Modzalevskaya, T. 2001. The Upper Silurian Kuba and Demid Formations and characteristics of vertebrates and brachiopods (the Central Urals, Ufa Amphitheatre). Stratigraphy. Geol. Correlations (in press).

Fredholm, D. 1988a. Vertebrates in the Ludlovian Hemse Beds of Gotland, Sweden. Geol. Fören. Stockholm Förhandl., 110, Pt. 2, 157-179.

Fredholm, D. 1988b. Vertebrate biostratigraphy of the Ludlovian Hemse Beds of Gotland, Sweden. Geol. Fören. Stockholm Förhandl., 110, Pt. 3, 237-253.

Fredholm, D. 1989. Silurian vertebrates of Gotland, Sweden. Lund Publ. Geol., 76.

Gailite, L. K., Ulst, R. Zh. \& Yakovleva, V. I. 1987. Stratotype and type sections of the Silurian of Latvia. Zinatne, Riga (in Russian).

Gross, W. 1968. Fragliche Actinopterygier-Schuppen aus dem Silur Gotlands. Lethaia, 1, 184-218.

Gross, W. 1969. Lophosteus superbus Pander, ein Teleostome aus dem Silur Oesels. Lethaia, 2, $15-47$.

Janvier, P. 1978. On the oldest known teleostome fish Andreolepis hedei Gross (Ludlow of Gotland), and the systematic position of the lophosteids. ENSV TA Toim. Geol., 27, 88-95.

Karatajūte-Talimaa, V. N. 1981. Microremains of vertebrates. In Ob"yasnitel'naya zapiska k skheme stratigrafii verkhne-silurijskikh otlozhenij Vaigachsko-Juzhno-Novozemel'skogo regiona (Nekhorosheva, L. V., ed.), pp. 88-192. Sevmorgeologiya, Leningrad (in Russian).

Klubov, B. A., Kachanov, E. I. \& Karatajūte-Talimaa, V. N. 1980. Stratigraphy of the Silurian and Devonian of Pioneer Island (Severnaya Zemlya). Izv. Akad. Nauk SSSR. Ser. Geol., 11, 50-56 (in Russian).

Kossovoj, L. S. \& Karatajūte-Talimaa, V. N. 1977. Ludlow and Downton of North Timan. Izv. Akad. Nauk SSSR. Ser. Geol., 12, 55-62 (in Russian).

Märss, T. 1982. Vertebrate zones in the East Baltic Silurian. In Ecostratigraphy of the East Baltic Silurian (Kaljo, D. \& Klaamann, E., eds.), pp. 97-106. Valgus, Tallinn.

Märss, T. 1986. Silurian vertebrates of Estonia and West Latvia. Fossilia Baltica, 1. Valgus, Tallinn (in Russian with extended English summary).

Märss, T. 1992. Vertebrate history in the Late Silurian. Proc. Estonian Acad. Sci. Geol., 41, 205214.

Matukhin, R. G. \& Menner, V. Vl. 1999a. Introduction. In Stratigrafiya silura $i$ devona arkhipelaga Severnaya Zemlya (Matukhin, R. G. \& Menner, V. Vl., eds.), pp. 3-6. SNIIGiMS, Novosibirsk (in Russian).

Matukhin, R. G. \& Menner, V. Vl. 1999b. Silurian and Devonian basins of the Severnaya Zemlya Region in the system of basins of the northern Central Siberia, northern Europe and western sector of Russian Arctic. In Stratigrafiya silura i devona arkhipelaga Severnaya Zemlya (Matukhin, R. G. \& Menner, V. Vl., eds.), pp. 147-163. SNIIGiMS, Novosibirsk (in Russian).

Matukhin, R. G., Menner, V. Vl. \& Kuršs, V. M. 1999. Structure of the sections. In Stratigrafiya silura i devona arkhipelaga Severnaya Zemlya (Matukhin, R. G. \& Menner, V. Vl., eds.), pp. 7-82. SNIIGiMS, Novosibirsk (in Russian). 
Modzalevskaya, T. L. \& Märss, T. 1991. On the age of the lower boundary of the Greben Regional Stage of the Urals. Proc. Estonian Acad. Sci. Geol., 40, 100-103 (in Russian).

Nekhorosheva, L. V. 1981. Regional and local stratigraphical units. In Ob"yasnitel'naya zapiska $k$ skheme stratigrafii verkhne-silurijskikh otlozhenij Vaigachsko-Juzhno-Novozemel'skogo regiona (Nekhorosheva, L. V., ed.), pp. 10-15. Sevmorgeologiya, Leningrad (in Russian).

Otto, M. 1991. Zur systematischen Stellung der Lophosteiden (Obersilur, Pisces inc. sedis). Paläont. Z., 65, 345-350.

Richter, M. \& Smith, M. 1995. A microstructural study of the ganoine tissue of selected lower vertebrates. Zool. J. Linn. Soc., 114, 173-212.

Schultze, H.-P. 1968. Palaeoniscoidea-Schuppen aus dem Unterdevon Australiens und Kanadas und aus dem Mitteldevon Spitsbergens. Bull. Brit. Mus. Nat. Hist. London Geol., 16, 341368.

Schultze, H.-P. 1977. Ausgangsform und Entwicklung der rhombischen Schuppen der Osteichthyes (Pisces). Paläont. Z., 51, 152-168.

Schultze, H.-P. 1996. Walter R. Gross, a palaeontologist in the turmoil of 20th century Europe. Modern Geology, 20, 209-233.

Shujskij, V. P. 1981. Facial-lithological peculiarities of the Upper Silurian and Lower Devonian reefs on the western slope of the Central Urals. In Biostratigrafiya i fauna srednego paleozoya Urala (Sapel'nikov, V. P. \& Chuvashov, B. I., eds.), pp. 96-110. IGiG UNTs AN SSSR, Sverdlovsk (in Russian).

Shurygina, M. V., Brejvel', M. G., Brejvel', I. A., Zenkova, G. G., Militsina, V. S. \& Yanet, F. E. 1981. Prridoli Series on the North and Central Urals. In Biostratigrafiya i fauna srednego paleozoya Urala (Sapel'nikov, V. P. \& Chuvashov, B. I., eds.), pp. 55-74. IGiG UNTs AN SSSR, Sverdlovsk (in Russian).

Talimaa, V. N. \& Mel'nikov, S. V. 1987. Extract from the decision of the colloquium "Significance of vertebrates for the Devonian stratigraphic schemes of Timan-Pechora Subregion". In Resheniya mezhvedomstvennogo stratigraficheskogo soveshchaniya po ordoviku i siluru Vostochno-Evropeiskoj platformy, 1984 g. (Kaljo, D. L., ed.), pp. 13-16. Izd. VSEGEI, Leningrad (in Russian).

Turner, S. 2000. New Llandovery to early Přidoli microvertebrates including Lower Silurian zone fossil, Loganellia avonia nov. sp., from Britain. In Palaeozoic Vertebrate Biochronology and Global Marine/Non-Marine Correlation. Final Report of IGCP 328 (Blieck, A. and Turner, S., eds.). Cour. Forsch.-Inst. Senckenberg, 223, 91-127.

Valiukevičius, J. J., Gladkovskij, V. T., Karatajūte-Talimaa, V. N., Kuršs, V. M., Mel'nikov, S. V. \& Menner, V. Vl. 1983. Silurian and Lower Devonian stratigraphy of Northern Timan. Izv. Akad. Nauk SSSR. Ser. Geol., 10, 53-64 (in Russian).

\section{ANDREOLEPIS'E (ACTINOPTERYGII) LEVIK EURAASIA PÕHJAOSA ÜLEMSILURIS}

\section{Tiiu MÄRSS}

Andreolepis'e soomuseid ja plaadikesi on leitud kuuest regioonist: Baltikumist, Briti saartelt, Põhja-Timaanist, Novaja ja Severnaja Zemlja saarelt ning Kesk-Uuralitest. Põhiliselt on määratud liigiks Andreolepis hedei Gross. KeskUuralite Ufa jõe läbilõike ülemsiluri Tabuska kihtidest lahustatud proovidest leitud plaadikeste, soomuste ja ühe oga skulptuuri põhjal on püstitatud liik Andreolepis petri sp. nov. Viimase soomused on suuremad ja kaetud arvukate 
pikiribidega, mille küljed on omakorda peenelt ribitatud. Plaadikeste ja oga skulptuur on lühikestest, ühinevatest ja hargnevatest ribikestest. Leiti ka üks lühikese suletud küljejoonekanaliga soomus. Andreolepis on eraldatud omaette sugukonda Andreolepididae fam. nov.

\section{PACПPOCTPAHEHИE ANDREOLEPIS (ACTINOPTERYGII) В ВЕРХНЕМ СИЛУРЕ СЕВЕРНОЙ ЧАСТИ ЕВРАЗИИ}

\section{Тийу МЯРСС}

Чешуи и маленькие пластинки экзоскелета Andreolepis найдены в шести регионах: в Балтийском регионе, на Британских островах, на Северном Тимане, на Новой и Северной Земле и на Среднем Урале. В основном они принадлежат виду Andreolepis hedei Gross. На основании отличающейся скульптуры чешуй и пластинок, найденных в табускинских слоях верхнего силура в разрезе реки Уфы (Средний Урал), выделен новый вид Andreolepis petri sp. nov. Чешуи этого вида более крупные и покрыты многочисленными продольными, почти параллельными ребрами, боковые участки которых, в свою очередь, покрыты мелкими ребрышками. Скульптура пластинок и одного шипа состоит из соединяющихся и разветвляющихся коротких ребер. Обнаружена одна чешуя с коротким закрытым каналом боковой линии. Род Andreolepis выделен в самостоятельное семейство Andreolepididae fam. nov. 